\title{
Un-accounted Violence: Women Domestic Workers during COVID-19 Funding
}

\section{Prachi Sharma $^{1 *}$ and Madhurima Goswami ${ }^{2}$}

${ }^{1}$ Student, Bharathidasan University, Tamil Nadu, India

${ }^{2}$ Associate Professor, Tezpur University, Assam, India

*Corresponding author: sharmaprachi1719@gmail.com (ORCID ID: 0000-0003-4117-9492)

Received: 14-03-2021

Revised: 29-05-2021

Accepted: 17-06-2021

\begin{abstract}
Northeast India was affected lately compared to the other parts of India in the first phase of COVID-19 in 2020. This had a devastating impact on the poor women who survived by doing domestic labor pre-COVID and during COVID times. Most of these women were independent working women, with or without supporting members in their families. There was unavailability and denial of essential services and resources, which made their situation worse. Since in India, a large number of female domestic workers are employed in private households. Female Domestic Workers generally workday long for wages that are below the minimum wage. There is no such safeguard to protect these domestic workers from exploitation and violence. This makes their work largely unregulated and denies them excess to fundamental rights with others. This paper focuses on the conditions of the domestic workers during the COVID-19. There is a need for the state and central governments to revise a draft law that complies with international standards.
\end{abstract}

\section{HIGHLIGHTS}

(0) The study focuses on the impact of COVID-19 on the Domestic Workers professional and family life.

( The mental and physical violence of the Domestic Workers during COVID-19 has resulted into acute poverty, loss of self dignity and identity.

(0 The National and International safeguards have been ineffective and have resulted drastically during COVID-19.

( The National Crime Records Bureau positions Assam, India as the first in the list having the maximum number of crimes against women.

Keywords: COVID-19, domestic workers, domestic violence, exploitation, gender justice, human rights

India was struck by an unprecedented crisis of COVID-19 in 2020. Along with that, the country also faced several natural disasters, including cyclones, landslides, and earthquakes, along with the pandemic. There were significant dismissals of jobs, closure of establishments, female face of migration, institutional layoffs etc. The immunization drive was restricted due to the unavailability and shortage of COVID vaccines.
The COVID-19 situation in the world had drastically impacted the gender dimension leading to inequalities, discriminations and violence in the societies. The nations witnessed large scale human migration, deaths,

How to cite this article: Sharma, P. and Goswami, M. (2021). Un-accounted Violence: Women Domestic Workers during COVID-19 Funding. Int. J. Soc. Sci., 10(02): 143-151.

Source of Support: None; Conflict of Interest: None (9) 9 
orphans and headless families. The economic scenario was hit by lockdowns. Though the $44^{\text {th }}$ Summit of the Group of seven wealthy nations, comprising of the US, UK, Canada, France, Germany, Italy and Japan met in England on June 11-13, 2021 to discuss the ordeal created by the pandemic resolved to build back better. This would show the value of democracy and the protection of human rights in the post COVID times.

In India, the first lockdown of three weeks was imposed on $24^{\text {th }}$ March within concise notice. There was a complete restriction of movement of the people, which led to hardships, difficulties, and resulted in challenges. The challenges were maintaining peace and tranquility within the families, ensuring strategies for survival, starting new ventures, imbalance, and division of labor in a social and professional context.

Even before COVID-19, the situation of the state Assam in India was no exception. According to the media reports: As released by the press, Guwahati, October 9, 2020, Assam Tribune (A local daily). "The Governor of Assam Jatiya Parishad has slammed the BJP governments in the state and centre for their total failure to ensure women's safety in Assam and across the country. Citing the latest NCRB data on Crime Against Women, the regional party's conveners Basanta Deka and Dr. K.G. Bhattacharya today said that at a time, the government made tall claims of women empowerment through slogans like 'Beti Bachao. Beti padhao', the overall situation of crime against women in the country, and particularly Assam's performance in the NCRB report present a picture in sharp contrast. 'Assam has topped the chart for the rate of crime against women in the country for the third consecutive year, as per the 2019 NCRB data. In 2017, the rate of crime against women in Assam was 143.3 (against one lakh women, whereas the corresponding national figure was 57.9. Again in 2018, the rate of crime against women in Assam increased to 166. It is almost three times the national average, and in 2019, crime against women in Assam has increased to 177.8 against the national average of 62.4 , "the AJP stated. As per the NCRB data, compared to 2018, the rate of crime against women in India has risen by 7.3 percent, with the country recording an average of 87 rape cases every day. The party also asked Chief Minister
Sarbananda Sonowal to explain as to why the condition of women has deteriorated in the state in the past three years. Another BJP ruled state Uttar Pradesh is in the headlines for gruesome incidents of rape and killing. It projects that women are not safe under the BJP rule, 'the party conveners said. The party further stated that unless there is a change in the country's socio-economic and political situation and adequate seats are reserved in the Lok sabha for women, the problems of women in India would continue to exist (The Assam Tribune: 2020).

Assam ranked among the worst-performing states like Uttar Pradesh and Bihar in the Sustainable Development Goals index of 2021. The state scored a total of 57 in the overall SDG index, which measured the performance of all the states in the achievement of the specific goals, which includes no poverty, clean water and sanitization, zero hunger, gender equality, quality education, good health, and well being, decent work and economic growth (Niti Aayog Report: 2021).

There are various reasons for the suffrage of women during COVID-19. Alcoholism is the most significant contributor (57 percent) to physical violence on women by their husbands. The sudden loss of income across a section of the male and female workforce in the state has led to distressed situations in households, with women facing the brunt of frustration and anxiety of the spouses and male members. Women can neither seek refuge elsewhere due to social distancing nor come out easily to register cases in police stations. The opening of 181 services in Assam during the lockdown witnessed an increase in registration of case related to spousal violence against women, which only reinforces the fact that women in the state may not have high incidence of dowry-related are highly vulnerable to spousal violence. (Choudhury, 2020).

\section{Statement of the problem}

Women Domestic Workers are doubly suppressed and discriminated against in their family and work life. They are paid a meagre sum of money for a variety of works that is not even permanent, with no job security. These women also go through a variety of physical abuses from their employers and family members that make 
them weak and vulnerable. Intimate partner violence is the most common phenomenon in contemporary times. This paper mainly highlights the cases of such domestic workers during the COVID-19 times when things went worse for them.

\section{Literature review}

This section reviews the literature related to domestic violence, domestic workers, and patriarchy. This pulls themes and perspectives from various researches done in the field of gender and violence. It also traces the historical process of subjugation by patriarchy in society. It also draws attention to the various arguments made in favor of the worker women. A range of issues intervening work and violence debate related to women is provided as arguments in this section.

The book 'Women and Crime' Mallicoat (2015) includes two contemporaries contemporary readings in each section, preceded by student-friendly authored introductions. The issues discussed include the history and theories of victimization issues, the processing and sentencing of female offenders, girls in the juvenile system, the supervision and incarceration of women, and women and work in the criminal justice system.

The book 'Domestic Violence-Problems and Solutions' Dr. Farzana Alim, Sukanta Sarkar (2015), is a collection of research papers that focus on various facets of domestic violence, its magnitude, and dynamics. The sources in the research papers are public agencies like police, courts, hospitals, and shelters. The second major source is from the random sample surveys, which claim to be much more representative of reality than agency data. The papers discuss, highlight various issues of violence from different perspectives.

The book 'The Diary of a Maidservant' Krishna Baldev Vaid (2007) critically focuses on the traits of the maidservant Shanti who embodies innocence, integrity, self respect, trust, defiance, and introspection. The novel describes how she reinvents herself by creating her own space and enriching it. It's a graphic rendering of the life of a domestic worker and their employers.

The book 'Empowerment and Status of women In Tripura' Kiran Shankar Chakrabarty (2008) includes a research paper titled 'Plight of the Part-Time Domestic Workers in Agartala' by Basu, Maitra, and Bhattacharya, which focuses on the socio-economic profile of the part-time domestic workers in Agartala, along with occupation and wage structure, examines their working background and tries to look for a scope of unionization, the process of collective bargaining.

The book 'Mapping The Field' Gender Relations In contemporary India, Nirmala Banerjee, Samita Sen, Nandita Dhawan (2012). The chapter 'A note on women as workers' by Nirmala Banerjee, discusses women's share in the benefits generated by development. The fundamental question raised is regarding the factors that make a worker a women worker. These women workers are just one segment of the total workforce, usually get stuck at the bottom end of the pile. Patriarchal control result in a lack of control over women's labour; flexibility, unpaid work, and self-regulation are some of the aspects that describe the general prototype of a woman worker.

\section{Significance of the study}

This research work is significant because FDW is unorganized workers with no labor laws to protect them or give job security. They are at a loss of human dignity and are seldom paid the dignity of labor. Not many studies are conducted in Assam. So, the researcher having a gender studies background feels the need for research in this area.

\section{Methodology}

The particular research study has been designed in a descriptive framework. It focuses on the problems of female domestic workers. The research has been done in Tezpur City of Assam, India. The universe of the study comprises of FDW of Kolibari village, Tezpur city, Assam. The researchers have used purposive sampling because of the COVID-19 protocols (complete lockdown). The sample size constituted of 25 Female Domestic Workers. The primary data was collected directly from the respondents during the second wave (April $21^{\text {st }}$ to May $\left.24^{\text {th }}\right) 2021$. The secondary data was collected from newspapers, news, international reports, and websites and from the studies that have been conducted. Besides, 
this case study and group discussion (maintaining social distancing was also used). Some of the cases have been cited.

\section{DISCUSSION}

\section{The Domestic Worker}

Female domestic workers are the neglected group among the unorganized sector. For decades they have been exploited and only in recent years NGO's are taking up the cause of women domestic workers (Joddar and Sakthivel, 2006) (Augustine and Singh, 2016).

Domestic work is one of the most essential informal occupations for millions of women around the world. Women have limited options and enter the domain of domestic work in the absence of education, economic resources, and other opportunities. The term "domestic service, Is practically challenging to define since the duties of domestic workers are not well defined. Domestic service is now accepted as an essential category of livelihood across the globe. Domestic service remains a highly personalized and informal service delivered in the homes of employers. In domestic service, work cannot be subjected to any comparative tests since it has the character almost unique in wage paid industry (Kodandarama, 2018).

The domestic worker is a multi-tasker with and without essential skills to do particular jobs. They perform routine and occasional tasks as and when demand is made. The routine work comprises of cooking, washing, mopping, dusting, nurturing, taking care of the elderly, and supporting the family from time to time, they do extra work to earn extra money. These are the people who do not have special skills or expertise, so they earn a paltry sum every month. The other workers have minimum education and are hired as domestic workers for their personality and presence. Some of them are well-groomed and people do not mind hiring them with a decent salary. The third set of workers doesn't work outside regularly but on request provide their services for which they are paid according to the work.

In the urban sphere, there are many NGO's like Maitrilivelihood services, in Assam etc., who provide domestic services at fixed rates. These women are from vulnerable backgrounds; they are trained in different fields like taking care of the babies, older adults who need support, special culinary skills, gardening, mending homes, etc. These women are offered salaries between seven to ten thousand. They have fixed working hours and weekends off. For extra work, extra money is charged. Somehow, these services have not been very successful because of less professionalism in work. After a specific time these women would walk out of their jobs without completing the contract.

\section{The International Domestic Workers Federation (IDWF)}

The International Domestic Workers Federation is an initiative of Domestic Worker's unions together with support organizations. It was formed in the year 2013. The objectives of the network are: to assist in the organizations of domestic workers' unions where they do not yet exist; to serve as a clearinghouse for the exchange of information; to organize mutual support and solidarity; to advance common political aims (international standards, national legislation); to represent domestic workers at the international level, and to secure the support of the broader labour movement for each of these objectives. (IDWN, 2013).

\section{National Domestic Workers Federation (NDWF)}

It's been more than 35 decades that NDWF has been formed. It was formed in the year 1985. It aims to protect, ensure and promote the rights of Domestic Workers in India and those working abroad through solidarity and participation. Its objectives are to ensure equal rights for domestic workers like any other workers regarding wages, social security, working conditions, health, and other benefits, etc. In October 2013, six state-level unions of domestic workers came together and organized its first congress of the federation. They finalized their constitution, elected their leadership, framed rules and policies. Initially named as National Domestic Workers Federation, it changed its name into National Domestic Workers Federation (Idwfed, 2014). 


\section{Domestic Workers Skill Conclave - Northeast}

The conclave aims to facilitate linkages among various stakeholders in the sector for improved service delivery for the clients and improved reward packages for the workers. The quintessence is achieving last mile connectivity and ensuring positive outcomes for the entire industry.

\section{Case study as a study design in qualitative research}

The feminist method is based on the assumption that challenges and confronts male supremacy that universalizes women's oppression. It attempts to analyze the main social differences between men and women. The present research tries to understand COVID-19 and its impact on Female Domestic Workers through the case study method.

In selecting a case, we usually use purposive, judgmental, or information-oriented sampling techniques. It gives a holistic understanding of the situation, phenomena, episode, group, or community. We select a case that can provide much information to understand the case in totality. Sufficient time and rapport must be built before any information is gathered. It is essential that during analysis, one considers the case as a single entity (Kumar, 1999).

\section{Case Studies}

\section{The life and struggle of Dharmeshwari Das, during COVID-19}

Dharmeshwari, aged 86, was born in a scheduled caste village named Kolibari, Sonitpur district, Assam. She was married at the young age of 10. She gave birth to six children, and she was pious and religious-minded, devoted towards her family. She was adept in all domestic chores and farm work, including care work of domesticated animals. The advent of COVID-19 was an enigma of Dharmeshwari. She was not bothered about maintaining protocols during the pandemic. She would regularly visit her workplaces for work. She would often wonder about the disease and the way it was creating destruction all over her village. She would generally dismiss it as the sin of the people on this earth. Though she was uneducated, she knew scriptures and would lead her life adhering to those philosophies. She would recite Bhagwata and would pray to God to end this pandemic. Unmindful she was regarding the tense situation that prevailed during the first wave of COVID-19. Gradually, the virus caught her, and she was not go to work regularly and would keep praying to God.

Though she helped everybody, her own life was a saga of tribulations. She has been through a lot of mental and physical violence during COVID times, as she could not go out to work, and her sons and daughters would have to give her food and care. The family, fearing that her last days are near, started abusing and stopped her three square meals a day. She was told to leave her house by her daughters instead of acquiring her property and money left in her accounts. They were assured that without food and medicines, she would die soon. She was hit by iron rods and stuck whenever she refused to part with her land papers. COVID-19 was a blessing in disguise for the family members. Though the family treated her in not so suitable manner, she would still be showering her motherly love on her children. Dharmeshwari had lost her self-dignity and her fundamental freedom to live her life. She ran from pillar to post to register FIR's at police stations on various accounts earlier. Now she was unable to move, and people were afraid to offer her help because of contagion. The continuous physical assault on her made her a mental wreck and resulted in the deterioration of her health day by day. She was pale and frail and knew that her end was near. Her everyday life became a text of bruises and wounds, many times, she would not return home on earlier occasions and stayed at different places. During COVID-19, she was confined strictly to her home.

\section{Analysis}

Her vulnerabilities started from a very young age; she was burdened with responsibilities of taking care of her six children and the private (domestic) work she did to run the family at a very young age. She was back broken all these years as this had taken a toll of her health. It seems she got abused more when she became physically weak. It was easy for her family members to damage her in- person psychologically. Though she was 
a strong lady, she was isolated in the village because of her family members. Poverty was also one of the major reasons for her suffering. COVID-19 added to her woes and miseries. Dharmeshwari died of COVID-19 a few days after she gave the interview for the research paper.

\section{Systematic discrimination of Kavita Das}

Kavita Das, aged 37 years, is educated up to the tenth standard, could not study further due to lack of money. Though she had training in jute and handloom weaving, her parents married an unemployed and alcoholic youth of a nearby village. The story of discrimination and exploitation starts from here. Kavita gave birth to two children, a boy and a girl, at a very young age. Her health condition was not good as she could not eat a nutritious diet during her pregnancy. She immediately resumed her domestic work without giving rest to her body. She was doubly burdened because she had to feed three mouths and her ailing mother in the family. She and her children were at risk of health problems because neither she was able to give them good food nor give them quality time. Pre-COVID-19 situation, for Kavita, was full of sorrows and subjugation. The initial months (first wave of COVID-19) were a little peace because she received her salary even without going out for work. She was with her children, her mother and tried to make harmony in the family. Her husband was happy to see her at home from morning to evening since she took care of them. Gradually, as months passed by, Kavita did not receive her salary as she completely stopped going out for work.

Kavita was gradually becoming a frustrated lady. She would throw tantrums at her mother and her husband. In return, she has hurled abuses and physical violence; the marks, and inflictions on her body were enough to speak her story. We could see her face turned black and blue as she comes to work the following day, even though she was told to abstain from work. Her face muscles would swell up, and she would often break down during her work. She would very often lie when it comes to physical violence met by her husband almost every day. One could see her breaking down physically and mentally day by day. She was trying to save every penny for her two children for their education by getting involved in temporary and occasional work.

\section{Analysis}

Access and availability of resources in terms of opportunities in an important parameter to measure the status of women in the society. Globally 75 per cent of the unpaid work is done by women. The term 'Working Women' is a tautology. There's no such thing as a woman who doesn't work. There is only a woman who isn't paid for her work (Caroline Criado - Perez). In a country like India, health issues of women are hardly taken care of by the family or society. The women have become vulnerable more in the pandemic as they are strictly confined to their homes. In Kavita's case, though she is educated and skilled, she could not find a suitable job, so continued working in informal sector where she is paid less wages with no job security.

\section{Jayanti Das, victimization in the times of COVID-19}

Jayanti Das who is above 80 years. She had two sons who never went to school, though they were always pampered by their alcoholic father, who never bothered to work and contribute towards the household. Once Jayanti's husband passed away, hell broke on her head. The two sons were engaged in vandalism and made it difficult for their mother to lead a peaceful life. To make ends meet, Jayanti started cooking, fetching water, child care, washing clothes, and many such as home care workers. People at times paid her and mostly she was left unpaid, but it was worse when the pandemic hit Assam. They would call her to work every alternate day but never bothered to pay any money. It was difficult for her to arrange for food and pay rent; whatever little money she had saved pre-pandemic, she had to take out from the bank. She was not able to buy her medicines and do health checkups. For her, food for her family members was more important than her medicine. Jayanti was tensed as for her; no work meant no pay. Her sons would ask for money now and then and would beat her up when she couldn't give them any. Jayanti was hardly bothered about the consequences of the pandemic. The story would not end there; she was regularly tortured for money and alcohol etc., during these difficult times. 


\section{Analysis}

Jayanti's case shows how a woman gets displaced in family and society simultaneously more so, during difficult times. Multiple roles of women lead to workload, stress, physical illness, mental illness, economic distress, depression, anxiety, and affects mental well-being of the women due to overburden of domestic and public work. One can see how, in a patriarchal society, how power equation works. Despite both the sons being half the age of their mother, they were able to dominate, exploit the working women in society. On the contrary, the experienced and aged women had no control of their lives. The everyday life of a domestic worker was a saga of pain and agony. The violence against women is unique in that the perpetrator is closely related to the women and mostly happens in the privacy of the home. Due to the private nature of this form of violence, its prevalence is estimated to be much more than we can imagine in pandemic times.

\section{Findings}

1. The number of FDW between the ages of 3545 is (55 percent) and $45-75$ is (45 per cent) were engaged in domestic work. Some were young, and some were old.

2. The present study shows that all 25 workers were from the scheduled caste.

3. All FDW's were Hindus. A few got married outside their caste.

4. Among the respondents, 50 percent were married females. 2 percent were unmarried and the rest were all widows.

5. Regarding the educational status of the respondents, 2 percent were educated, and the rest had never been to school.

6. Most of the female domestic workers belonged to joint families. 2 percent were from nuclear families.

7. It is found in the study that more than 90 percent of the FDW used to work in the morning and evening shifts. 10 percent used to work in a single shift for five to six hours. During a pandemic, the FDW became workless and insecure.
8. So far, theearningsearned by FDW have contributed significantly to the family's total income. With COVID-19, there was a deficit of earnings which led to the poor position of the women in the family. The study found that 50 percent of the FDW were trying to look for alternative work such as agriculture and petty business. The rest 50 per cent didn't possess land to do agriculture nor had investments to start a business.

9. In terms of work (occupation, above 90 percent) were single earning members. A few respondents headed the family's occupation: rickshaw pullers, fish mongers, and vegetable sellers.

10. The study shows that the monthly income of the respondents was ₹ 2000 to 3000 . This money was used for buying everyday essentials, rent, medicine etc.

11. The study shows that except for 5 percent, the rest of the respondents had their own houses. Rest was staying on rent.

12. According to the present study, the impact of COVID-19 was more on the FDW as the economic condition of the respondents was below the poverty level. The restriction and termination of jobs added to the economic distress.

13. The extra income of FDW that was generated during the festivals (Bihu, Durga puja, several occasions) as rewards/bonuses or gifts was not received during this period.

14. Staying in homes for 24 hours added to the physical strain and physical violation for more than 90 percent of FDW.

\section{CONCLUSION}

The COVID 19 has created an atmosphere of anxiety and stress among the human population. The pandemic has become serious threat to human development. Irrespective of sex, class, caste and gender, the COVID-19 crisis has affected everyone. The women are more and disproportionately subjugated in patriarchal violence, social situations and power imbalances. It is important for the national policy makers to formulate plans and programs to integrate safety services to counter violence 
against women. The civil society can act as frontline workers by bringing up shelter homes and counseling during the pandemic. This will include providing them separate spaces along with isolation needs and medical assistance. Provision for online services for reporting and during violence. Policy should also take care of the children who need childcare and also parental assistance. Distribution of ration (food) and ensuring access to health and sanitation needs should be ensured. For mobility issues public services run by women enterprises should be encouraged. This will not only contest inequalities and oppressions but will also build a gender just world.

In Assam, violence against women is seen on the rise, as reported by the NCRB data. Thinking along the lines, Assam has been placed in the number one position in relation to violence against women. Violence against women in different forms and measures in the state. It is true that for many, the statistics related to NCRB data are not reliable. The entire northeast is considered as a region that respects women in the public and private sectors. Yet, the levels of violence against women are very high, among the highest in India. Within Northeast India, there are two spatial contexts, the familiar context, and the external non- familiar contexts. In the northeast, the number of violence's against women perpetrated by the people outside the household is the highest in India. The most significant of this is the militarization of the entire region. It comes from the armed forces, Paramilitary groups, and local militant groups organized along the ethnic lines. Coinciding with COVID-19, it was observed that the attitude and behavior towards FDW by the employers had no limitations. The extra payment for extra work was not an act of kindness but the mercy of the employers. The study brings out firmly that FDW's are unaware of any social security measures. NGO's working for their rights, legislations etc. The FDW's FDW's vulnerability is due to the socio-economic conditions, illiteracy, patriarchy, lack of skill remains a question in the $21^{\text {st }}$ century.

Since times immemorial, the subjugation of FDW is due to a series of discriminations, deprivations, and undignified labour. The interventions, legal safeguards, and platforms to raise voices for their rights are absent.
Societies look down upon attitude makes them socially weak and politically disadvantaged section of the society. However, recently the Government of India has tabled a Bill against Sexual Harassment incorporating domestic workers within its ambit. The effectiveness of the Bill will prove lowering down harassment and violence. It requires sustainable measures, awareness, and sensitization for effective implementation of the law.

\section{Suggestion}

1. There is a stringent need for sensitization, awareness and motivation regarding rights and life skills of the FDW.

2. The disaster management act should incorporate provisions for vulnerable people (FDW) in the difficult times.

3. An immediate concern by the local, national and International groups, NGO's, social activists, government organizations, state and national commissions for women, policy makers, and civil society interventions will show light of the day.

\section{ACKNOWLEDGEMENTS}

We are grateful to the women workers of the Kolibari Village, Tezpur, Assam, who provided us with information, work details during long hours of interaction. Their patience, understanding had widened our views regarding their lives. Without their help and cooperation, this indebt study would not have been successful.

\section{REFERENCES}

Assam Tribune, 2020. Govt failed to ensure women's safety: AJP, p-1-2 (https://headline8.in/news/assam/ajp-slams-bjp-fortotal-failure-in-ensuring-women-safety/) or https://epaper. assamtribune.com/full-page-pdf/epaper/pdf/2020/10/09/theassam-tribune/2204?infinitescroll=1. (Accessed on $7^{\text {th }}$ April 2021)

Augustine, R. and Singh, R. 2016. Conditions \& problems of Female Domestic workers (With Special Reference to L.D.A Colony in Lucknow City, India), J. Socio. Social Work, 4(2): 110117.

Choudhury, S. 2020. COVID -19 and Women in Assam: Some Issue, Research gate Publication, pp. 2. (https://www.researchgate. 
net/publication/341820898_COVID_-19_and_Women_in_ Assam_Some_Issues). (Accessed on $15^{\text {th }}$ May 2021).

Domestic workers skill conclave (https://asdm.assam.gov.in/ events/domestic-workers-skill-conclave-chapter-north-east). (Accessed on $2^{\text {nd }}$ June 2021).

International Domestic Workers Federation, 2013. (https:// www.wiego.org/resources/international-domesticworkers-federation-idwf\#: :text=The $\% 20$ International $\% 20$ Domestic\%20Workers\%20Federation, union's\%20together\%20 with $\% 20$ support $\% 20$ organizations) . (Accessed on $9^{\text {th }}$ June 2021).

Kodandarama, C. 2018. Women Domestic Workers in India: An Analysis, Int. J. Innov. Technol. Explor. Eng. (IJITEE), 8: 1-4.

Kumar, R. 1999. Research methodology - a step-by step guide for beginners, $3^{\text {rd }}$ edition, Sage Publications, pp. 127.

National domestic workers federation, 2014. https:/idwfed.org/ en/affiliates/asia-pacific/national-domestic-workers-tradeunions-federation-ndwtuf. (Accessed on 12 ${ }^{\text {Th }}$ June, 2021.
Niti Aayog reports 2020-21. https://www.pratidintime.com/ assam-ranks-worst-performer-in-niti-aayog-sdg-index-reportraijor-dal/.

Rana, R. 2020. India Lockdown: Most affected is Unorganized Sector; It is 93 per cent of the total workforce 41 crore people lack economic security. https:/www.inventiva.co.in/stories/ riyarana/india-lockdown-most-affected-is-unorganizedsector-it-is-93-of-the-total-workforce-41-crore-people-lackeconomic-security/. (Accessed on $9^{\text {th }}$ June 2021).

Rivera, C, Chieh-Hsu, Yu., Pavez Esbry, F. and Dugarova, E. 2020. Gender Inequality and COVID-19 Crisis: A Human Development Perspective, (Human Development Working paper in collaboration with Human development report office and the Gender team, UNDP, pp. 3. 
